\title{
IS THE COMPLETION OF EU SINGLE MARKET HINDERED BY VAT EVASION?
}

\author{
CHANG WOON NAM \\ ANDREA GEBAUER \\ RÜDIGER PARSCHE
}

CESIFO WORKING PAPER No. 974

CATEgory 1: Public Finance

JUNE 2003

\footnotetext{
An electronic version of the paper may be downloaded

- from the SSRN website: $\quad$ www.SSRN.com

- from the CESifo website: www.CESifo.de
} 


\title{
IS THE COMPLETION OF EU SINGLE MARKET HINDERED BY VAT EVASION?
}

\begin{abstract}
The planned movement to the origin principle with the cross-border pre-tax system on a fullscale would lead, ceteris paribus, to changes in VAT revenues in the individual EU countries. For instance, the member countries with trade surpluses and higher VAT rates would be significantly better off. For this reason, a clearing mechanism is necessary to rectify this type of revenue imbalance among the EU nations. The introduction of the Single Market in 1993 appears to have further encouraged firms' and households' evasive behaviour in paying VAT in the EU. In order to estimate its relevance, this study quantifies the annual amount of hypothetical VAT revenues for the individual countries on the basis of the national accounts data. The relation between the calculated hypothetical and the (current) collected revenues in a fiscal year largely determines the extent of VAT evasion of a country when the time-lag problem between the creation of tax liability and the VAT collection in cash terms can be adjusted. The macroeconomic clearing is supposed to take place based on the share of hypothetical revenues of the member countries. Consequently, such a system seriously suffers from the adverse incentives for the individual nations since countries with a lower evasion ratio than the weighted average of all EU countries would lose the VAT revenues, whereas those with a higher evasion ratio would gain.
\end{abstract}

JEL Code: F02, K42, O17, H25, H26, H87.

Keywords: VAT evasion, EU single market, origin and destination principle, hypothetical VAT revenues macroeconomic clearing national accounts.

Chang Woon Nam

Ifo Institute for Economic Research

Poschinger Str 5

81679 Munich

Germany

nam@ifo.de
Andrea Gebauer

Ifo Institute for Economic Research

Poschinger Str 5

81679 Munich

Germany

gebauer@ifo.de

Rüdiger Parsche

Ifo Institute for Economic Research

Poschinger Str 5

81679 Munich

Germany

parsche@ifo.de 


\section{Introduction}

Despite the introduction of the Single Market and the abolition of border controls, the so-called destination principle still dominates in the EU, particularly concerning the application of value added tax (VAT) on the commodity trade between the member states. The transitional arrangement existing since the beginning of 1993 is planned to be completely replaced by the so-called origin principle with the cross-border pre-tax refund system. "Border controls have [traditionally] been an important cornerstone of the European VAT system, since they [have] provided evidence of border-crossing transactions, thus verifying the entitlement for zero-rating upon exports as well as the obligation to pay import VAT" (Genser, 2002, p. 3). By contrast, the origin principle has largely been applied for the cross-border shopping of private households in the EU. ${ }^{2}$ For instance, consumers pay VAT of the origin country. EU citizens have been carrying out this type of trade without any quota restriction since 1993.

Ceteris paribus the planned movement to the origin principle with the cross-border pre-tax system on a full-scale would, however, lead to changes in VAT revenues in the individual EU countries. For instance, those member countries with trade surpluses (i.e. higher export volumes) and higher VAT rates would be significantly better off. For this reason, a clearing mechanism is necessary to rectify this type of revenue imbalance among the member states in the case of implementing the origin principle to collect VAT in the EU (Dziadkowski, 1997). Even though all the EU members have the same VAT rate, the clearing mechanism still appears to be necessary as long as net exports among countries differ (see Figures 1 and 2). According to the work programme developed by the European Commission for a common VAT system in 1996, the sum of VAT revenues collected by national authorities is anticipated to be redistributed to the national treasuries by a supranational apportionment of EU-wide VAT revenues ac

1 The transitional VAT regime has been criticised mainly for three reasons: "(i) VAT regulations on supplies and acquisitions of firms residing in different EU countries deviate from VAT regulations for transactions among resident firms. This asymmetry causes non-symmetric compliance costs which have been regarded as an untenable violation of the concept of a genuine single market and create a border tax burden [that] discriminates against intra-community trade [...]. (ii) The deferred payment system breaks the VAT chain at a very vulnerable stage, [for example] at the borderline of domestic and foreign tax administration. This weakness in VAT control may be exploited by VAT frauds, given the fact that in the EU there is a permanent and huge flow of commodities which circulate free of VAT after the export VAT rebate in the exporting country has been granted and before the deferred VAT payment in the importing country becomes effective. (iii) Differing national VAT rates provide incentives for price arbitrage to consumer and for strategic VAT rate competition among EU governments, which lead to unintended and undesirable revenue shifts between national treasuries as a consequence of strategic undercutting of VAT rates" (Genser, 2002, p. 6).

2 There are some exceptions to this general rule, as the destination principle is still applied for special regimes including household purchases of new motor vehicles, mail ordering, etc. 
cording to national accounts data. There have already been several attempts aimed at examining the possibilities of VAT clearing in the EU on the basis of such data (Nam, Parsche and Schaden, 2001). ${ }^{3}$

Figure 1 Intra-EU Trade and Destination Principle

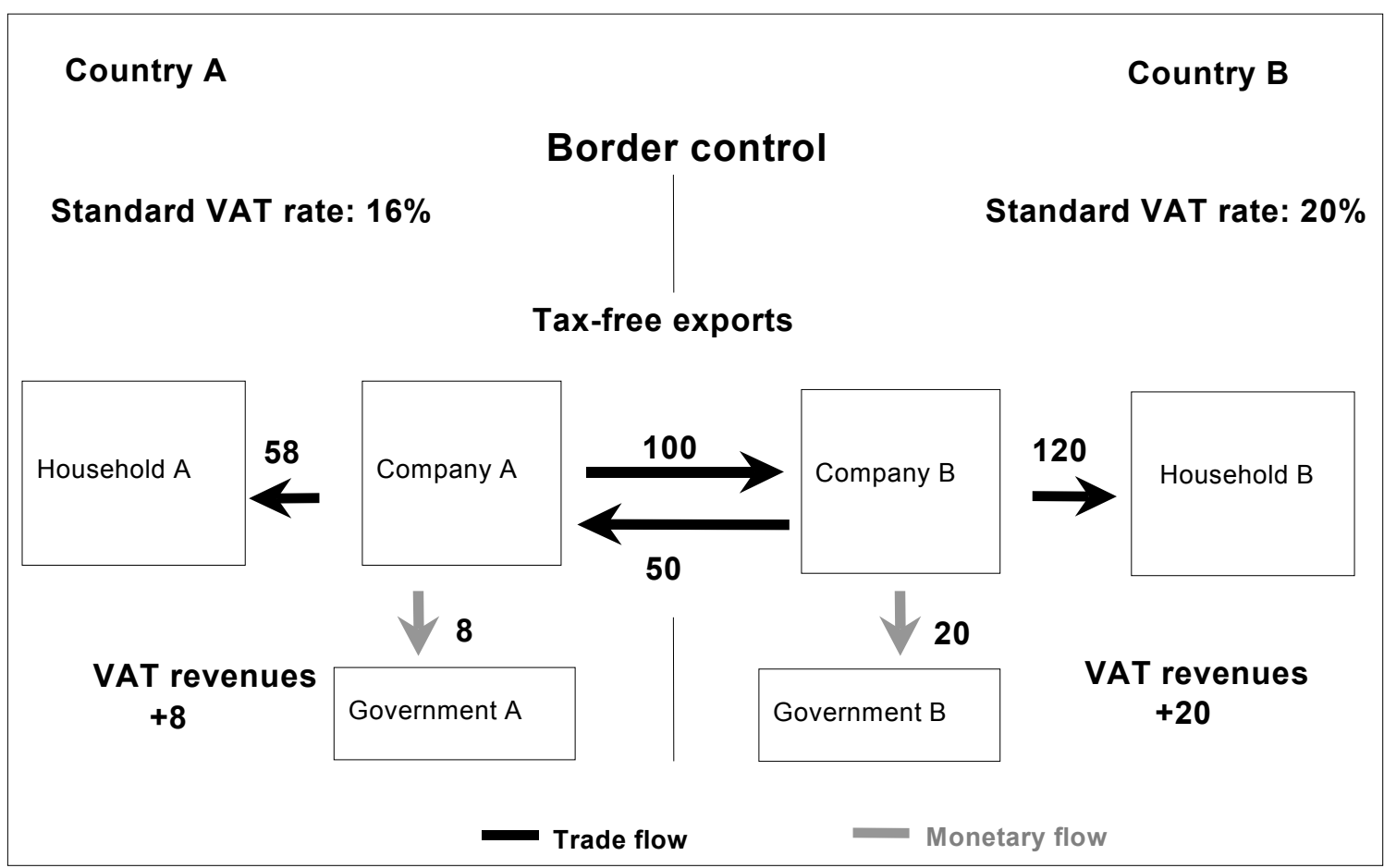

Source: Ifo Institute for Economic Research

Although there are debates about the definition of tax evasion and the shadow economy, both seem to be increasing steadily in the EU (Schneider and Enste, 2000; Schneider, 2000b; Lubell, 1991; OECD, 1997). ${ }^{4}$ In particular, the burden of direct and indirect

3 Theoretically the VAT clearing based on intra-EU trade statistics would be the correct method. Yet such an approach would suffer from the low quality of relevant data collected in the context of one EU market.

4 The definition of shadow or hidden economy has always been a controversial issue in the academic discussion (see e.g. Schneider and Enste, 2000; Lippert and Walker, 1997; Mogensen et al., 1995; Lubell, 1991; Feige, 1989; Frey and Pommerehne, 1984). One commonly adopted working definition is that "the shadow economy is market-based production of goods and services whether legal or illegal, that escapes detection in the official estimates of GDP.... [Apart from the illegal activities it also] includes unreported income from the production of legal goods and services, either monetary or barter transactions, hence all economic activities that would generally be taxable were they reported to the tax authorities" (Schneider and Enste, 2000, p. 79). The definition often varies depending on the selected method of measurement: Schneider and Enste (2000) primarily concentrate on legal valueadded creating activities which are not taxed or registered, while the study made by Andreoni, Erard and Feinstein (1998) exclusively deals with tax evasion and avoidance. In the former study, for example, unpaid household production, voluntary non-profit services and criminal activities are excluded from the analysis. 
taxation, the complexity of the entire tax and social transfer system as well as the intensity of government regulation have been empirically identified as the major causes of encouraging such illegal or hidden economic activities (Lippert and Walker, 1997; Johnson, Kaufmann and Schleifer, 1997; Frey, 1989; Frey and Pommerehne, 1984; De Gijsel, 1984; Riebel, 1983; Schneider and Neck, 1993; Tanzi, 1982). To a certain extent, the implementation of the Single Market appears to have increasingly stimulated firms' and households' evading behaviour with regard to paying value added taxes in the EU Member States. ${ }^{5}$

Figure 2 Intra-EU Trade and Origin Principle

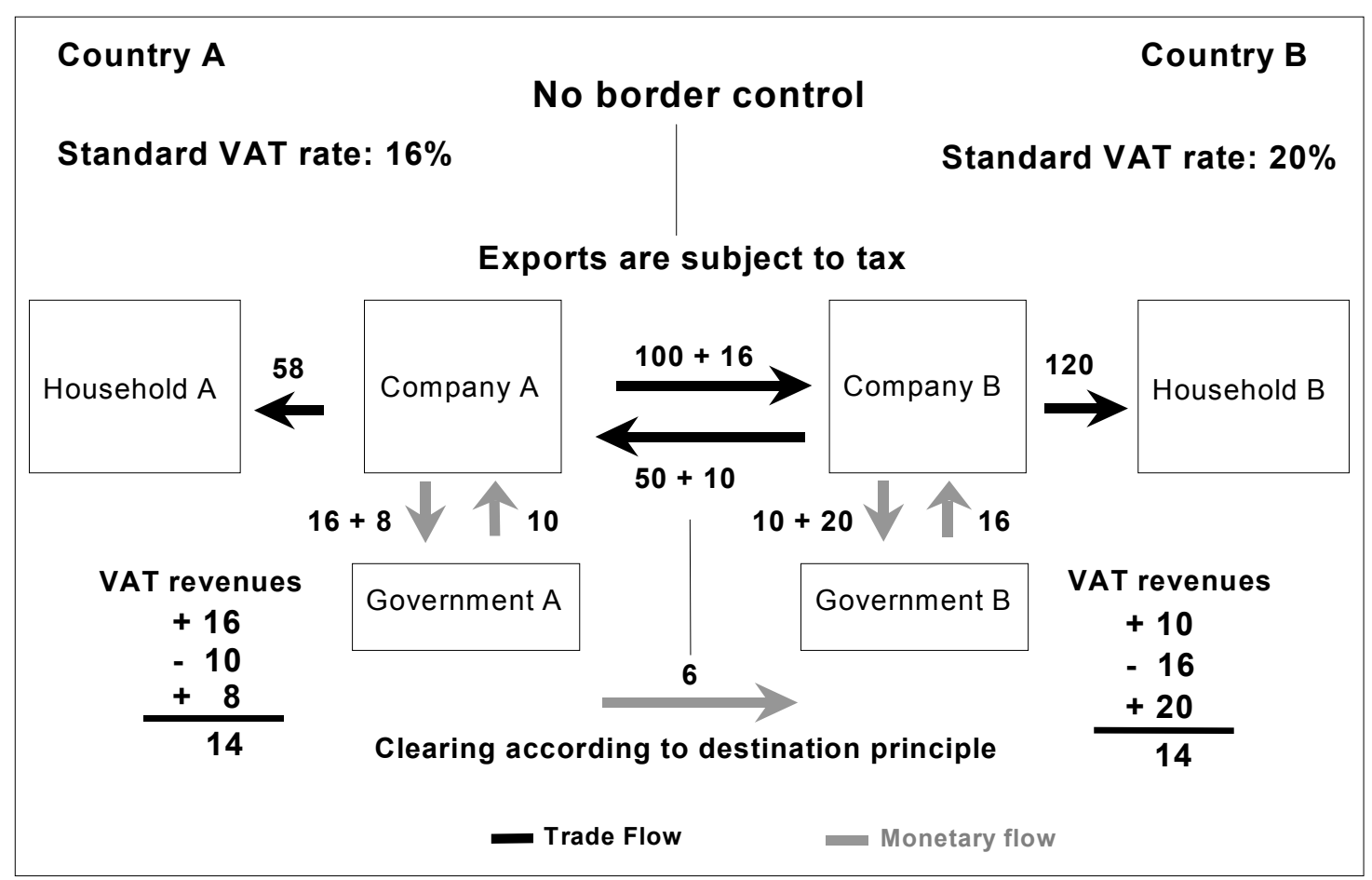

Source: Ifo Institute for Economic Research

In other words, the abolition of the border controls for intra-EU trade accompanied by the less well-established administrative co-operations of the (rather problematic) nationspecific EDP (electronic data processing) control systems has probably provided further opportunities to easily implement their VAT evasion efforts in the EU (Gebauer et al., 2002; Parsche, Steinherr and Waller, 1996). ${ }^{6}$

5 In OECD countries general consumption taxes, especially value added tax (VAT), are among the fastest growing revenue sources, together with contributions to finance social security. The former tax item produced ca. $18 \%$ of total tax revenues in 1998 , compared with only $12 \%$ in the mid-1960s (OECD, 1999).

6 VAT control is still a national task in the EU. Yet the Commission is highly interested in effective taxation and control in all member states, since VAT contributes to the EU budget. Today, the need for 
Different types of empirical methods have been adopted to measure the size of tax evasion and the informal economy, which range from a direct survey to a sophisticated, dynamic econometric model. All these methods have both advantages and shortcomings (Schneider, 2000a and 2000b; Schneider and Enste, 2000; Lippert and Walker, 1997; Feige, 1989). According to Schneider (2000a) and Thomas (1992), these approaches have a three-fold differentiation:

- micro approaches based on surveys (e.g. about income declared for tax purposes) among taxpayers and tax auditing (Isachsen, Klovland and Strom, 1982; Mogensen, Kvist, Körmendi and Pedersen, 1995),

- macroeconomic approaches calculating the differencies between income and expenditure statistics (MacAfee, 1980; Del Boca, 1981) as well as between the official (i.e. registered) and actual labour force (Contini, 1981); the monetary approach based on the Fisher quantity equation (Feige, 1996); the popular currency demand method measuring the correlation between the currency demand and the tax pressure (Tanzi, 1982); and the physical input method observing relations between (official and unofficial) GDP and electricity consumption (Kaufmann and Kaliberda, 1996; Johnson, Kaufmann and Schleifer, 1997; Lacko, 1998), and

- (dynamic) multiple-indicator and multiple-cause econometric models which consider various macroeconomic determinants for creating a shadow economy (i.e. the burden of taxation and regulation, tax morality, etc.) and attempt to explain their effects in the development of production, labour and money markets simultaneously (Aigner, Schneider and Ghosh, 1988; Schneider, 2000a; Frey and Weck-Hannemann, 1984).

Unlike the larger share of conventional empirical analyses which emphasise the predominance of direct taxation and measure the total size of tax evasion for the entire domestic economy of a country, this study deals with the narrow aspect of tax evasion in the specific area of EU value added taxation. On the basis of national accounts data, one can estimate the annual amount of hypothetical VAT revenues of the individual EU countries, which are assumed to be the maximum level of VAT revenues the country

audits under the transitional VAT system is much greater than before 1993, when cross-border transactions were interfered with border controls. However, insufficient financial resources are presently provided by the individual countries for this purpose. In addition, EU Member States have kept their own (nation-specific) VAT control methodology in spite of the creation of the internal market. Furthermore, some countries and regions are unwilling to improve tax controls, for this could reduce competitive advantages of indigenous firms against those foreign companies with higher tax compliance. Nowadays, the tasks regarding the administration and control of VAT matters are increasingly transferred to local and regional authorities. Emphasising the so-called subsidiarity principle, this development can be positively interpreted as a necessary measure to enhance control efficiency, since the local authorities have better information about local taxpayers. On the other hand, such an assignment could more easily lead to permitting tax evasion and fraud on the local level (Europäische Kommission, 1995, 1997 and 2000). 
can ideally collect in a fiscal year. When the mismatch in timing between creation of tax liability and VAT collection in cash terms can be adjusted, the relation between the hypothetical and the (current) collected revenues indicates the tax collection performance of a country, from which the extent of VAT evasion and fraud (as well as suspension of tax claims caused by bankruptcies) can also be derived for the same country. Furthermore, the macroeconomic clearing is supposed to take place based on the share of hypothetical revenues of the individual countries. Yet the macroeconomic clearing system seriously suffers from the adverse incentives for the individual EU Member States, since countries with a lower VAT evasion ratio than the weighted average of EU 15 would lose VAT revenues, whereas those with a higher evasion ratio would gain through such an EU-wide redistribution system.

\section{Method of Calculating VAT Evasion Based on National Accounts Data}

As mentioned above, this study primarily compares the difference between the hypothetical and the collected VAT revenues in a given fiscal year to determine the extent of VAT evasion and fraud in each EU country. The latter can be easily obtained from the official statistics, while the former should be estimated for comparison purposes. For the calculation of the hypothetical VAT revenues of a country, national accounts data and input-output tables published by the national statistical office, annual reports of various state-owned companies and other relevant statistics are adopted as the VAT base. ${ }^{7}$ In particular, the statistics and data on private consumption, intermediate consumption and investment of central and local governments (mainly for acquiring real estate, buildings, machinery, instruments etc.) apparently play the most important role for the assessment, together with those on the business performance of banks and insurance companies which are not entitled to deduct input VAT.

\footnotetext{
To a significant extent shadow activities are currently included in the national accounts of the individual EU countries. Yet the methods for correcting official statistics for this purpose still vary from one country to another. The European System of Accounts (ESA) of 1995 prescribes adopting all possible approaches to quantify (implicit and explicit) additions so that illegal and hidden economic activities can be exhaustively included in GDP. Even if this goal were achieved, the exact share of shadow activities would not seem to be easily identified. In general, national statistical offices can hardly provide detailed information on the part of GDP attributed to these shadow activities. Only some sectorspecific, explicit additions are relatively well captured in the relevant statistics and can be separated rather easily. There is no doubt that the major share of VAT evasion in the areas of private consumption as well as intermediate consumption and investment of governments and other specific sectors like banks and insurance companies, non-profit private institutions, etc. which are not entitled to deduct input VAT is included in the macro-economic aggregates. This study aims at identifying the scope of VAT evasion hidden in the national accounts data.
} 
Prior to the adjustment of the time-lag between the creation of tax liability and the real tax collection (see below), the hypothetical VAT revenues of a given fiscal year $u$ $\left(V A T_{u}^{h y p}\right)$ can be generally expressed as

$$
\begin{aligned}
V A T_{u}^{h y p}= & \sum_{i=1}^{n}\left(t_{Z, u} \alpha C_{i, u}+t_{R, u} \beta C_{i, u}+t_{N, u} \gamma C_{i, u}\right) \\
& +\sum_{i=1}^{n}\left(t_{Z, u} \alpha K_{i, u}^{g}+t_{R, u} \beta K_{i, u}^{g}+t_{N, u} \gamma K_{i, u}^{g}\right)+\sum_{j=1}^{m}\left(t_{R, u} \delta I_{j, u}^{g}+t_{N, u} \varphi I_{j, u}^{g}\right) \\
& +\sum_{i=1}^{n}\left(t_{Z, u} \alpha K_{i, u}^{o}+t_{R, u} \beta K_{i, u}^{o}+t_{N, u} \gamma K_{i, u}^{o}\right)+\sum_{j=1}^{m}\left(t_{R, u} \delta I_{j, u}^{o}+t_{N, u} \varphi I_{j, u}^{o}\right) \\
& +\sum_{i=1}^{n}\left(t_{Z, u} \alpha K_{i, u}^{f}+t_{R, u} \beta K_{i, u}^{f}+t_{N, u} \gamma K_{i, u}^{f}\right)+\sum_{j=1}^{m}\left(t_{R, u} \delta I_{j, u}^{f}+t_{N, u} \varphi I_{j, u}^{f}\right) \\
& +\sum_{i=1}^{n}\left(t_{Z, u} \alpha K_{i, u}^{h}+t_{R, u} \beta K_{i, u}^{h}+t_{N, u} \gamma K_{i, u}^{h}\right)+\sum_{j=1}^{m}\left(t_{R, u} \delta I_{j, u}^{h}+t_{N, u} \varphi I_{j, u}^{h}\right) \\
& +\sum_{i=1}^{n}\left(t_{Z, u} \alpha K_{i, u}^{l}+t_{R, u} \beta K_{i, u}^{l}+t_{N, u} \gamma K_{i, u}^{l}\right)+\sum_{j=1}^{m}\left(t_{R, u} \delta I_{j, u}^{l}+t_{N, u} \varphi I_{j, u}^{l}\right) \\
& +\sum_{i=1}^{n}\left(t_{Z, u} \alpha K_{i, u}^{p}+t_{R, u} \beta K_{i, u}^{p}+t_{N, u} \gamma K_{i, u}^{p}\right)+\sum_{j=1}^{m}\left(t_{R, u} \delta I_{j, u}^{p}+t_{N, u} \varphi I_{j, u}^{p}\right)
\end{aligned}
$$

where

$t_{Z}, t_{R}$ and $t_{N}=$ the net zero, reduced and normal VAT rates;

$u=$ a given fiscal year;

$i=$ consumptive product or service items $(i=1,2, \ldots, \mathrm{n})$;

$j=$ items of investment goods $(j=1,2, \ldots, \mathrm{m})$;

$\alpha, \beta$ and $\gamma=$ the sales shares of consumptive products and services which are taxed differently $(\alpha+\beta+\gamma=1)$;

$\delta$ and $\varphi=$ sales shares of investment goods which are taxed differently $(\delta+\varphi=1)$;

$C=$ final consumption of private households;

$K^{g}=$ intermediate consumption of (central and local) governments;

$I^{g}=$ investment made by (central and local) governments;

$K^{o}=$ intermediate consumption of non-profit private organisations;

$I^{o}=$ investment made by non-profit private organisations;

$K^{f}=$ intermediate consumption of banks and insurance companies;

$I^{f}=$ investment made by banks and insurance companies;

$K^{h}=$ intermediate consumption in the market-oriented health service sector;

$I^{h}=$ investment made in the market-oriented health service sector; 
$K^{l}=$ intermediate consumption in the sector of house and apartment rental;

$I^{l}=$ investment made in the sector of house and apartment rental;

$K^{p}=$ intermediate consumption of other public or non-profit private institutions (like postal service, lottery, etc.);

$I^{p}=$ investment made by other public or non-profit private institutions (like postal service, lottery, etc.).

In the quantification of hypothetical VAT revenues, for example, the component 'private consumption' of the national accounts data is differentiated into taxable and non-taxable (or tax-exempted) categories. As indicated in the national VAT law, the normal and the reduced rates are then allocated systematically corresponding to the individual items of private consumption, from which one can calculate the hypothetical VAT revenues for this area. Yet, it should be borne in mind that the national accounts data on private consumption are generally expressed in gross terms, which means that these values already contain the VAT amounts. As a consequence, the so-called gross VAT rates are used for the calculation purpose instead of the net tax rates.

The gross VAT rate at year $u\left(t_{u}^{*}\right)$ is defined as

(2) $t_{u}^{*}=\frac{t_{u}}{1+t_{u}}$

where $t_{u}=$ the net VAT rate at year $u$.

In the case that a consumption position cannot be entirely assigned to a VAT rate but encompasses a number of sub-items which are subject to different tax rates, a weighted gross rate is implied. The weighting scale for the total position is usually derived from the different shares of the sub-items in this consumption category (see Table a1 and a2 in Appendix). 
Table 1 Value added tax rates in the EU Member States

(Net) VAT rates in $1996^{\mathrm{a}}$

Normal rate in $\%$

Reduced rate in $\%$

\begin{tabular}{lr} 
Austria & 20 \\
Belgium & 21 \\
Denmark & 25 \\
Finland & 22 \\
France & 20.6 \\
Germany & 15 \\
Greece & 18 \\
Ireland & 21 \\
Italy & 20 \\
Luxembourg & 15 \\
Netherlands & 17.5 \\
Portugal & 17 \\
Spain & 16 \\
Sweden & 25 \\
United Kingdom & 17.5 \\
\hline
\end{tabular}

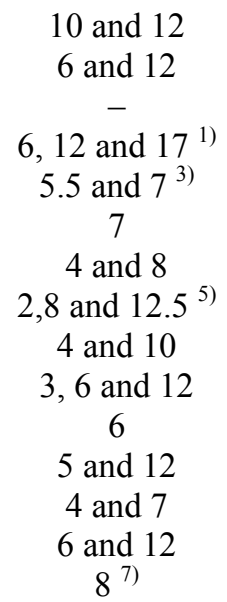

a In this study the quantification for the selected EU Member States is carried out for the years 1994, 1995 and 1996. Due to this reason, the 1996 VAT rates are indicated here.

b In general the reduced rates are imposed on the consumption of agricultural products, foodstuffs, books, and certain medical and pharmaceutical products and equipment as well as paintings and antiques. Exports are subject to the zero rate.

1) Since 1 January 1998 only two reduced rates: $8 \%$ and $17 \%$.

2) Since 1 January 2000: $19.6 \%$.

3) Since 1 January 2000: $2.1 \%$ and $5.5 \%$.

4) Since 1 April 1998: 16\%.

5) The lower reduced rate continuously changed thereafter: $3.3 \%$ (1997), 3.6\% (1998), 4\% (1999), 4.2\% (2000) and 4.3\% (2001).

6) Since 1 January 2001: $19 \%$.

7) Since 1 January 1997: 5\%.

Source: Gebauer et al. (2002), Möglichkeiten und Risiken der Einführung eines grenzüberschreitenden Vorsteuerabzugs auf europäischer Ebene, Munich; Europäische Kommission (2002), Generaldirektion Steuern und Zollunion, Steuerpolitik, DOC/2908/2002 - DE, May 2002; Mennel and Förster (1999), Steuern in Europa, Amerika und Asien, Herne/Berlin.

Analogously one can also measure the input VAT burden (i.e. on intermediate consumption and investment) of governments, banks and insurance companies, private nonprofit organisations as well as those activities and industries like private lessons, renting houses and apartments, market-oriented health services, postal services, lotteries, etc. which are, due to the tax-free (or exempt) sales of goods and services, not subject to the input tax deduction in most cases. Special tax regimes like the flat rate taxation for farmers, the taxation of margins for travel agencies, and the SME-specific rule cause some additional efforts in collecting and elaborating relevant statistics, for these firms are also allowed to opt for the normal taxation. Furthermore, it should be additionally taken into account that in many countries the input tax deduction is (fully or partially) 
limited also for taxable private firms when purchasing certain services and durable (investment) goods like cars and corresponding expenditures for maintenance and repair work as well as gasoline.

Some quantification difficulties may arise when the territorial scope of the VAT law does not tally with the territorial reporting area covered by the national accounts (see the case of Åland Island with the mainland of Finland). The same applies when the VAT law provides for tax rates that differ by region (see the case of Corsica in France). In both cases, a precise quantification is possible only if corresponding regional statistics are available. An additional measuring problem can emerge when certain items are recorded in the national accounts which are not connected with purchases of relevance for VAT purposes (e.g. imputed rents for house or apartment owners), and in particular when these items are not indicated separately but incorporated into other items, with the result that a recalculation is hardly possible.

A more serious problem for the quantification of VAT evasion based on national accounts data is caused by the discrepancy between the tax revenues on an origin basis (i.e. the creation of tax liability) and the collected cash revenues in a given period of time. The latter differs from the former owing mainly to the factors like payment periods, back payments and deferred payments. In other words, the calculation of hypothetical revenues for a fiscal year is made on the basis of current national accounts data, which delivers therefore the sum of VAT revenues on an origin basis for the same year. In practice however the VAT imposed on household consumption (and on the investment and intermediate consumption of governments, financial institutions, private nonprofit organisations, etc.) made at the end of December of the preceding year, for example, can only be effectively (i.e. in cash terms) transferred by firms to tax authorities in January of the current year. At present this type of formal VAT collecting process usually takes approximately a month (see e.g. the case in Germany). As a consequence, a significant share of tax revenues actually originated from the purchases of goods and services in December of the preceding year is (in cash terms) collected later and recorded as January revenues of the current fiscal year. For the adjustment of such a timelag problem the January revenue value of the individual years is thus particularly relevant. Since the monthly amounts of collected tax revenues are hardly ever available for the investigated EU Member States, a tenth of the preceding year's revenues on an origin basis is simply allocated for all countries (except Spain) as the part of the corre 
sponding type of VAT revenues for the current fiscal year. ${ }^{8}$ Furthermore, an additional deduction of $1 \%$ of revenues on an origin base of a fiscal year is made in the quantification to adequately consider the significance of suspending tax claims caused by bankruptcy and other types of tax waiving of the same year. ${ }^{9}$

After the necessary time-lag and minor adjustments mentioned above are made, $V A T_{u}^{h y p}$ is transferred to $\operatorname{VAT}(\operatorname{adj})_{u}^{\text {hyp }}$.

(3) $V A T(\operatorname{adj})_{u}^{h y p}=(1-\phi)\left[\omega \cdot V A T_{u-1}^{h y p}+(1-\omega) \cdot V A T_{u}^{h y p}\right]$

where $\phi=$ the share of suspending tax claims due to bankruptcy and other tax waivings and $\omega=$ the share of VAT revenues of which collection in cash term takes place in the successive year. In this study these parameters are assumed to be constant over the investigated years $(\phi=1 \%$ and $\omega=10 \%$ for all EU countries except Spain with 30\%).

As a consequence, the tax collection performance ratio at year $u\left(r_{u}^{c o l}\right)$ is

(4) $\quad r_{u}^{c o l}=\frac{V A T_{u}^{c o l}}{\operatorname{VAT}(a d j)_{u}^{h y p}}$

where $V A T_{u}^{c o l}=$ the collected VAT revenues in cash term at year $u$.

Hence, the ratio of VAT evasion at year $u\left(r_{u}^{\text {eva }}\right)$ can be formally defined:

(5) $r_{u}^{\text {eva }}=1-r_{u}^{c o l}$.

8 Spain is an exception. Regardless of reduced or normal rates, this country increased its VAT rate by $1 \%$ in 1995 . Due to the three month tax payment period, the collected VAT revenues in 1995 contain in the first quarter the revenues from the lower taxes $(3 \%, 6 \%$ and $15 \%)$ and the rest from the higher ones (4\%, $7 \%$ and $16 \%)$. The corresponding time-lag adjustment is made on the basis of this fact.

9 Such types of statistical adjustment and deductions can be done more accurately by national statistical offices on the basis of nation-specific method and period of tax payment, seasonal fluctuation of consumption and tax income as well as insight information on bankruptcies and other sorts of tax waiving. 


\section{Major Findings of the Empirical Analyses on VAT Collection Per- formance and VAT Evasion in Germany and the EU}

As shown in Table 2, Germany suffered from a rapid growth of VAT evasion in the three subsequent years after the introduction of Single Market in 1993: $r_{u}^{\text {eva }}$ derived from the comparison of the quantified (adjusted) hypothetical and the collected revenues increased from $1.6 \%$ (1994) to $7.5 \%$ (1996). In part this development can be interpreted as the outcome of increased tax evading efforts of German firms (and also households) which were triggered by the abolition of borders for the intra-EU trade as well as the insufficient (national and EU-wide) tax control and administration in the Single Market. More importantly, the relative low evasion ratio of 1994 appears to be well led by the technical difficulties in collecting VAT emerged at the initial year of the Single Market. For this reason a more significant (than for other investigated years assumed) share of VAT revenues assigned to the fiscal year 1993 seems to have been actually collected in the succeeding year. If such a time-lag effect could be adjusted properly, $r_{u}^{\text {eva }}$ would presumably reach around 4\% in 1994 .

Table 2 Changes of the adjusted hypothetical and the collected VAT revenues as well as the ratio of VAT evasion in Germany (1994-2001)

\begin{tabular}{c|c|c|c}
\hline Year & $\begin{array}{c}V A T(a d j)_{u}^{\text {hyp }} \\
(\text { billion } €)\end{array}$ & $\begin{array}{c}V A T_{u}^{c o l} \\
(\text { billion } €)\end{array}$ & $\begin{array}{c}r_{u}^{\text {eva }} \\
(\%)\end{array}$ \\
\hline 1994 & 122.5 & 120.5 & 1.6 \\
1995 & 126.4 & 119.9 & 5.1 \\
1996 & 131.0 & 121.2 & 7.5 \\
1997 & 132.0 & 123.2 & 6.7 \\
1998 & 139.0 & 127.9 & 8.0 \\
1999 & 146.6 & 137.2 & 6.4 \\
2000 & 151.5 & 140.9 & 7.0 \\
2001 & 153.8 & 138.9 & 9.7 \\
\hline
\end{tabular}

Source: Calculation of the Ifo Institute for Economic Research, Munich.

Since 1996 the annual evasion ratio has fluctuated within a narrow band between $6 \%$ and $8 \%$, although the same rate reached a rather high level of around $10 \%$ in 2001 . The decrease in $r_{u}^{\text {eva }}$ from $8.0 \%$ (1998) to 6.4\% (1999) appeared to be led by the introduction of the so-called Tax Relief Law (Steuerentlastungsgesetz 1999/2000/2002) at the beginning of 1999, which among others limits the pre-tax refund for firms' travel expenses and other costs related to the usage of cars for business purposes. This legal change in tax base mobilised additional VAT revenues in cash term in 1999 (and also in 
2000), of which fiscal effect should also be adequately taken into account for the quantification of hypothetical tax revenues: these values were officially reported to be $€ 1.6$ and 2.3 billion for the years 1999 and 2000, respectively (Dziadkowski et al., 2002). Yet these numbers appear to be underestimated and, due in part to this reason, the measured $r_{u}^{\text {eva }}$ was relatively low in 1999 and 2000 .

Unlike the projected $€ 2.5$ billion growth at the beginning of 2001, Germany's current (collected) VAT revenues decreased by approximately $€ 2$ billion in 2001 and reached only $€ 139$ billion. Rather surprisingly such a trend was accompanied by an increase in (macroeconomic) VAT base. The total sum of evasion amounted to about $€ 14$ billion in 2001, to which an amount of ca. $€ 4$ billion was contributed by the fast expansion of the so-called (tax-avoiding) daisy-chain businesses (Karussellgeschäfte) within the EU (Dziadkowski et al., 2002). Consequently, the German legislative body installed at the beginning of 2002 an extra liability provision ( $\$ 25 d$ Umsatzsteuergesetz - UStG) through the law of prohibiting tax avoidance (Steuerverkürzungsbekämpfungsgesetz - StVBG) in order to fight, first of all, the establishment of such businesses.

Table 3 Comparison of adjusted hypothetical and collected VAT revenues in the selected EU Member States for 1994-1996 (in billion national currency)

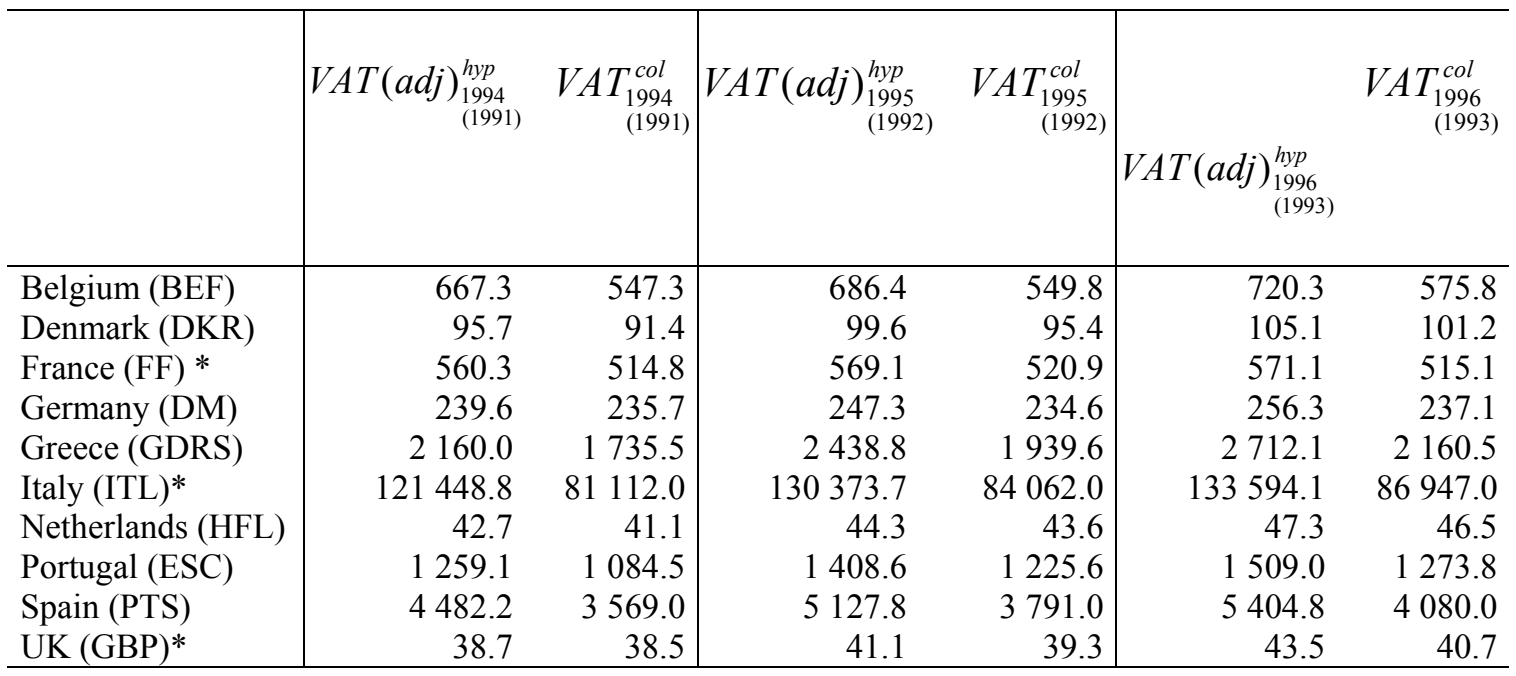

* For the countries France, Italy and the United Kingdom, annual hypothetical VAT revenues were calculated by Parsche, Steinherr and Waller (1996) for the period 1991-1993. Their calculation was based on the old national statistical system prior to the introduction of the European System of Accounts (ESA) in 1995, in which these countries compiled and classified economic data according to their own rules and definitions. Compared to the cases in France and Italy, the size of shadow economy was less sufficiently considered and included in the UK when calculating the country's national accounts data for the years between 1991 and 1993.

Sources: National accounts and tax revenue statistics of the investigated countries (Eurostat, 1997), National Accounts ESA 1980-1995, Luxembourg/Brussels; Calculations of the Ifo Institute for Economic Research, Munich. 
Table 4 Ratio of tax evasion $\left(r_{u}^{e v a}\right)$ in the selected EU Member States for 19941996 (in \%)

\begin{tabular}{lcccc}
\hline & 1994 & 1995 & 1996 & Average \\
& $(1991)$ & $(1992)$ & $(1993)$ & \\
\hline Belgium & 18.0 & 19.9 & 20.1 & 19.3 \\
Denmark & 4.5 & 4.3 & 3.8 & 4.2 \\
France * & 8.1 & 8.5 & 9.8 & 8.8 \\
Germany & 1.6 & 5.1 & 7.5 & 4.8 \\
Greece & 19.8 & 20.5 & 20.3 & 20.2 \\
Italy & 33.2 & 35.5 & 34.9 & 34.5 \\
Netherlands & 3.8 & 1.7 & 1.6 & 2.4 \\
Portugal & 13.9 & 13.0 & 15.6 & 14.2 \\
Spain & 19.2 & 24.6 & 24.0 & 22.6 \\
UK * & 0.4 & 4.4 & 6.5 & 3.8 \\
\hline
\end{tabular}

* See Table 3.

Sources: National accounts and tax revenue statistics of the investigated countries; Eurostat (1997), National Accounts ESA 1980-1995, Luxembourg/Brussels; Calculations of the Ifo Institute for Economic Research, Munich.

Table 3 and 4 summarise the tax collection performance and the VAT evasion ratio for the selected EU Member States in the period 1994-1996. For France, Italy and the UK the corresponding values for the years between 1991 and 1993 are adopted for comparative purposes (Parsche, Steinherr and Waller, 1996). Among those investigated nations, Italy, Spain, Greece and Belgium had the highest VAT evasion and fraud rates in the observed years which are derived from the lowest tax collection performance figures. By contrast, tax evasion appears to be less serious in the Netherlands, Denmark and the UK, which have recently enjoyed tax collection performance values of around $95 \%$ in the same period of time. Furthermore, while the ratio of VAT evasion and fraud more or less stagnated on a high level in Italy and Greece, the same ratio tended to slightly decrease in the low tax evasion countries like Denmark and the Netherlands between 1994 and 1996.

By and large these empirical results correspond well to the major outcomes of the previous studies by Schneider and Enste (2000) and Schneider (2000b) which quantify the size of the shadow economy (as a percentage of official GDP) in advanced economies based on the so-called currency demand approach (Table 5). ${ }^{10}$ A positive correla

10 Although the direct correlation between the average VAT evasion ratio in Table 4 and the share of the shadow economy measured by Schneider and Enste (2000) in Table 5 appears to be less significant shown in terms of the Pearson's correlation coefficient of 0.003 , the strong interrelationship between the two measures can be well identified, when a simple regression analysis (ignoring the constant c) is carried out, adopting the latter variable as the dependent and the former as the independent one. In this case the development of the size of shadow economy in the EU is expressed and also explained as a 
tion between the extent of tax evasion and the level of VAT rates appears to be less distinct in the investigated years (see the low evasion ratio of Denmark with the high normal rate of $25 \%$ and the vice versa for Spain with $16 \%$ in Table 5). To a certain extent, this finding conflicts with the general argument for broadening the tax base and lowering tax rates to reduce the economic incentive to go underground. Yet it should also be emphasised, taking the Danish experience as an example, that tax evasion can be effectively reduced by (a) simplifying the administration of various taxes, (b) imposing tough enforcement, (c) increasing international co-operation for sharing tax information and (d) building a better information base for tax evasion with resources of statistical office, ministries of finance and tax authorities, etc.

Table 5 Comparison of the rankings of the 1996 VAT rate level and the average VAT evasion ratio for 1994-1996 as well as the average shadow economy size as \% of GDP for 1994-1995 in the investigated EU countries

\begin{tabular}{lccc}
\hline & $\begin{array}{c}\text { Ranking of the normal } \\
\text { VAT rate in 1996 } \\
\text { from highest to lowest } \\
\text { (based on Table 1) }\end{array}$ & $\begin{array}{c}\text { Ranking of the average } \\
\text { VAT evasion ratio for } \\
\text { 1994-96 from highest to } \\
\text { lowest }\end{array}$ & $\begin{array}{c}\text { Ranking of the average shadow } \\
\text { economy size as \% of GDP for } \\
\text { 1994-95 from highest to lowest } \\
\text { (based on Schneider and Enste, }\end{array}$ \\
\hline Denmark & 1 & 8 & $2000)$ \\
Belgium & 2 & 4 & $6(17.8 \%)$ \\
France & 3 & 6 & $5(21.5 \%)$ \\
Italy & 4 & 1 & $7(14.5 \%)$ \\
Greece & 5 & 3 & $2(26.0 \%)$ \\
Netherlands & 6 & 10 & $1(29.6 \%)$ \\
United Kingdom & 6 & 9 & $8(13.7 \%)$ \\
Portugal & 8 & 5 & $10(12.5 \%)$ \\
Spain & 9 & 2 & $3(22.1 \%)$ \\
Germany & 10 & 7 & $9(22.4 \%)$ \\
\hline
\end{tabular}

* The ranking for France, Italy and the United Kingdom is made on the basis of the average VAT evasion ratio for 1991-93.

Source: Table 1 and 4; Schneider and Enste (2000), Shadow Economies: Size, Causes, and Consequences, Journal of Economic Literature, Vol. 38, No. 1, Table 7, p. 104. 


\section{Reasons for Lacking Control Incentives for Macroeconomic Clearing in Individual EU Member States}

In the following it is suggested that the recommended macroeconomic clearing system seriously suffers from the adverse incentives of the individual EU Member States. Such a revenue redistribution system will lead to an erosion of national efforts in collecting VAT and in controlling its evasion properly (Genser, 2002). ${ }^{11}$ If the macroeconomic clearing takes place and different VAT evasion rates prevail in the EU, there will be some shifts of national VAT revenues caused by the movement from the destination to the origin principle. The actual (collected) VAT revenues of the member country 1 at the given year $u$ can be described in a simplified form as follows, when the destination principle applies

(6) $\quad \operatorname{VAT}(D E S)_{1, u}^{c o l}=r_{1, u}^{c o l} \cdot t_{1, u}^{w} \cdot B_{1, u}$

where $t_{1, u}^{w}=$ the weighted VAT rate and $B=$ the tax base that can be defined as

$$
\begin{aligned}
B_{1, u}=\sum_{i=1}^{n} & C_{i u}+\sum_{i=1}^{n} K_{i u}^{g}+\sum_{j=1}^{m} I_{j u}^{g}+\sum_{i=1}^{n} K_{i u}^{o}+\sum_{j=1}^{m} I_{j u}^{o}+\sum_{i=1}^{n} K_{i u}^{f}+\sum_{j=1}^{m} I_{j u}^{f}+\sum_{i=1}^{n} K_{i u}^{h}+\sum_{j=1}^{m} I_{j u}^{h} \\
& +\sum_{i=1}^{n} K_{i u}^{l}+\sum_{j=1}^{m} I_{j u}^{l}+\sum_{i=1}^{n} K_{i u}^{p}+\sum_{j=1}^{m} I_{j u}^{p}
\end{aligned}
$$

On the other hand, the hypothetical VAT revenues for the same country and year can be characterised as

(7) $V A T_{1, u}^{h y p}=t_{1, u}^{w} \cdot B_{1, u} \cdot$

Consequently,

$$
\frac{\operatorname{VAT}(D E S)_{1, u}^{c o l}}{V A T_{1, u}^{h y p}}=\frac{r_{1, u}^{c o l} \cdot t_{1, u}^{w} \cdot B_{1, u}}{t_{1, u}^{w} \cdot B_{1, u}}=r_{1, u}^{c o l}
$$

11 Under the macroeconomic clearing regime, national tax authorities remain responsible for VAT administration. According to Genser (2002), the optimum tax collecting effort level is a crucial economic matter, for higher efforts cause higher costs. The national government will invest an additional euro in such an effort, as long as tax revenue will rise by one euro or more. This type of marginal incentive system works if additional tax revenue flows directly back to the national budget. Yet European revenue sharing in the frame of macroeconomic clearing creates a positive fiscal externality setting and for this reason rational governments tend to be less keen on the carrying-out of intensive tax collection. In other words the level of VAT collection effort of the individual countries will be inefficiently low, unless the positive fiscal externalities of national VAT collection are fully internalised. Ceteris paribus the revenue shortfall will be the higher, the smaller the clearing ratio (i.e. $z$ in equation (10)) for the country. For instance, if the Dutch VAT administration were able to collect a marginal revenue increment of $€ 100$, then the consumption-based macroeconomic clearing would increase the country's VAT revenue only by $€ 4$ (Genser, 2002). 
The term $y_{1, u}$ shows the share of country 1's collected VAT revenues at year $\mathrm{u}$ as $\%$ of the total amount of VAT revenues in the EU at the same year:

(9) $y_{1, u}=\frac{V A T(D E S)_{1, u}^{c o l}}{\sum_{s=1}^{15} \operatorname{VAT}(D E S)_{s, u}^{c o l}}=\frac{r_{1, u}^{c o l} \cdot t_{1, u}^{w} \cdot B_{1, u}}{\sum_{s=1}^{15}\left(r_{s, u}^{c o l} \cdot t_{s, u}^{w} \cdot B_{s, u}\right)}$

where the total number of EU Member States $s=15$ at present.

Since $y_{1, u}$ will not be any longer known in the case of implementing the origin principle, the macroeconomic clearing should be carried out based on the so-called clearing ratio $(z)$ for the country 1 at the year $u$

(10) $z_{1, u}=\frac{t_{1, u}^{w} \cdot B_{1, u}}{\sum_{s=1}^{15}\left(t_{s, u}^{w} \cdot B_{s, u}\right)}$.

As a consequence, the VAT revenues to be distributed to the country 1 after the macroeconomic clearing at the year $u\left(V A T_{1, u}^{M C}\right)$ amounts to

(11) $V A T_{1, u}^{M C}=z_{1, u} \cdot \sum_{s=1}^{15} \operatorname{VAT}(O R I)_{s, u}^{c o l}$

where $\operatorname{VAT}(O R I)_{1, u}^{c o l}$ means the current amount of VAT revenues for the country 1 at the year $u$, when the origin principle is adopted.

In addition, the intra-EU delivery of goods from the country 1 to the country 2 will be subject to tax in the country 2 if the origin principle with the cross-border input-tax reimbursement system applies. The transfer of the VAT system will definitely cause certain changes in VAT revenues for the individual countries and also for total EU revenues, since the tax rate and the control intensity in member states will continue to remain quite different. Yet it appears to be hardly possible to measure such revenue changes that would be contributed by the movement from the destination to the origin principle. For this reason it is assumed for the further analysis that the total sum of collected VAT revenues on the EU level at $u$ remains unchanged. This assumption would be satisfied if tax rates were completely harmonised EU-wide.

(12) $\sum_{s=1}^{15} \operatorname{VAT}(\mathrm{ORI})_{s, u}^{c o l}=\sum_{s=1}^{15} \operatorname{VAT}(D E S)_{s, u}^{c o l}=\sum_{s=1}^{15}\left(r_{s, u}^{c o l} \cdot t_{s, u}^{w} \cdot B_{s, u}\right)=$ constant 
For the country 1 the shift of VAT revenues share in the EU at $u$ caused by the macroeconomic clearing compared to the case with the destination principle can be illustrated as

$$
\text { (13) } \frac{V A T_{1, u}^{M C}}{V A T(D E S)_{1, u}^{c o l}}=\frac{z_{1, u} \cdot \sum_{s=1}^{15}\left(r_{s, u}^{c o l} \cdot t_{s, u}^{w} \cdot B_{s, u}\right)}{r_{1, u}^{c o l} \cdot t_{1, u}^{w} \cdot B_{1, u}}=\frac{z_{1, u}}{\frac{r_{1, u}^{c o l} \cdot t_{1, u}^{w} \cdot B_{1, u}}{\sum_{s=1}^{15}\left(r_{s, u}^{c o l} \cdot t_{s, u}^{w} \cdot B_{s, u}\right)}}=\frac{z_{1, u}}{y_{1, u}} \text {. }
$$

The modification of equation (13) provides

$$
\text { (14) } \begin{aligned}
\frac{V A T_{1, u}^{M C}}{\operatorname{VAT}(D E S)_{1, u}^{c o l}} & =\frac{z_{1, u} \cdot \sum_{s=1}^{15}\left(r_{s, u}^{c o l} \cdot t_{s, u}^{w} \cdot B_{s, u}\right)}{r_{1, u}^{c o l} \cdot t_{1, u}^{w} \cdot B_{1, u}}=\frac{\frac{t_{1, u}^{w} \cdot B_{1, u}}{\sum_{s=1}^{15}\left(t_{s, u}^{w} \cdot B_{s, u}\right)} \cdot \sum_{s=1}^{15}\left(r_{s, u}^{c o l} \cdot t_{s, u}^{w} \cdot B_{s, u}\right)}{r_{1, u}^{c o l} \cdot t_{1, u}^{w} \cdot B_{1, u}} \\
& =\frac{\sum_{s=1}^{15}\left(r_{s, u}^{c o l} \cdot t_{s, u}^{w} \cdot B_{s, u}\right)}{r_{1, u}^{c o l} \cdot \sum_{s=1}^{15}\left(t_{s, u}^{w} \cdot B_{s, u}\right)}=\frac{r_{E U, u}^{c o l}}{r_{1, u}^{c o l}} .
\end{aligned}
$$

where $r_{E U, u}^{c o l}=\frac{\sum_{s=1}^{15}\left(r_{s, u}^{c o l} \cdot t_{s, u}^{w} \cdot B_{s, u}\right)}{\sum_{s=1}^{15}\left(t_{s, u}^{w} \cdot B_{s, u}\right)}$ is the weighted average tax collection performance ratio for the EU at the year $u$.

Equation (14) shows that an EU Member State with a lower VAT evasion ratio $\left(r_{u}^{\text {eva }}=1-r_{u}^{c o l}\right)$ than the weighted average of EU 15 would lose the VAT revenues, whereas those with a higher evasion ratio would gain through the EU-wide macroeconomic clearing system. 


\section{Conclusion}

Ceteris paribus the movement from the destination to the origin principle with the crossborder pre-tax system would lead to changes in VAT revenues in the individual EU Member States. Since those countries with trade surplus and higher VAT rates would be significantly better off, a clearing mechanism is necessary to adjust this type of revenue imbalance. According to the 1996 proposal of the European Commission, such a redistribution is anticipated to take place based on the share of hypothetical VAT revenues of the EU countries, of which the sum is basically derived from the national accounts data.

This study quantifies the amount of hypothetical VAT revenues for the individual countries and compares this sum with the (current) collected revenues in a fiscal year. The difference between these two types of annual revenues largely determines the extent of VAT evasion of a country. According to such empirical analyses, Germany had a relatively strong growth of VAT evasion between 1993 and 1996. This trend was not only triggered by the increased tax evading opportunities caused by the borderless Europe and the insufficient national and EU-wide tax control system in a new economic framework but also largely led by the technical difficulties in collecting VAT, liability for which was created at the initial year of the Single Market. Consequently a large share of VAT revenues (assigned to the year 1993) was actually collected in the succeeding year, which, in turn, contributed to the reduction of the evasion ratio in 1994. The significant decrease of the same rate in 1999 could be in part explained by the inclusion of underestimated increases of hypothetical revenues in the calculation, which was led by the limitation of the pre-tax refund system for some specific business expenses in the context of the Tax Relief Law 1999/2000/2002. Although the macroeconomic VAT base expanded, Germany's current (collected) VAT revenues decreased by around $€ 2$ billion in 2001. As a consequence, the VAT evasion ratio reached $10 \%$ at the same year. About one third of the total evasion amounting to $€ 14$ billion seems to have originated from the rapidly expanding daisy-chain businesses in the EU.

In the international comparison for the period between 1994 and 1996, countries like Italy, Spain, Greece and Belgium suffered particularly from serious tax evasion and fraud. By contrast, the average tax collection performance ratio was quite high in the Netherlands and Denmark. In general these empirical findings correspond well with the outcomes of a number of previous investigations which quantify the size of the shadow economy in advanced economies based on different types of approaches. Since the daisy-chain businesses have continuously grown EU-wide, such a development would also significantly affect the recent size of VAT evasion in other EU Member States. In this context the study suggests that the reduction of VAT evasion in member nations to 
an acceptable level is one of the most crucial prerequisites to accomplish the 'true' European Single Market equipped with the origin principle.

Yet, this study also underscores that the macroeconomic clearing system will lead to an erosion of national efforts in collecting VAT and in controlling evasion properly in the individual EU countries. A member nation with a lower VAT evasion ratio than the weighted average of EU 15 is likely to lose VAT revenues, while those with a higher evasion ratio tend to gain through such a supranational redistribution system.

Last but not least, it should be borne in mind that the quantification of hypothetical VAT revenues and the determination of evasion ratio depend very strongly on the quality of national accounts data, input-output tables and other relevant official statistics as well as VAT revenue data available for the individual countries. 


\section{Appendix: Calculation of Hypothetical VAT Revenues - An Example for Private Consumption in Italy (1991-1993)}

\section{Table a1 Final consumption of private households in Italy (1991-1993)}

\begin{tabular}{|c|c|c|c|c|c|c|}
\hline \multirow{2}{*}{$\begin{array}{l}\text { Statistical positions for } \\
\text { products \& services }\end{array}$} & \multicolumn{3}{|c|}{$\begin{array}{l}\text { Private consumption including } \\
\text { VAT in billion Italian Lire (ITL) }\end{array}$} & \multicolumn{3}{|c|}{$\begin{array}{c}\text { Gross VAT rates }\left(t_{u}^{*}\right) \\
\text { in } \%\end{array}$} \\
\hline & 1991 & 1992 & 1993 & 1991 & 1992 & 1993 \\
\hline Bread \& cereal & 19935 & 21190 & 22065 & 3.8 & 3.8 & 3.8 \\
\hline Meat ${ }^{1)}$ & 44744 & 46684 & 49116 & 14.2 & 14.2 & 14.2 \\
\hline Fish $^{2)}$ & 10454 & 11072 & 11180 & 6.9 & 8.5 & 8.5 \\
\hline Milk, cheese \& eggs ${ }^{3)}$ & 22996 & 23919 & 25145 & 5.1 & 5.1 & 5.1 \\
\hline Oil \& fat ${ }^{4)}$ & 6387 & 6579 & 6593 & 4.1 & 4.1 & 4.1 \\
\hline Fruit \& vegetables & 38730 & 41465 & 38505 & 3.8 & 3.8 & 3.8 \\
\hline Sugar, coffee, tea $\&$ cacao & 5775 & 5995 & 6139 & 8.3 & 8.3 & 8.3 \\
\hline Other foodstuffs ${ }^{5)}$ & 5328 & 5604 & 5849 & 8.3 & 8.3 & 8.3 \\
\hline Non-alcoholic beverages ${ }^{6}$ ) & 3556 & 3867 & 4099 & 16.0 & 16.0 & 16.0 \\
\hline Alcoholic beverages ${ }^{7)}$ & 9402 & 9771 & 9970 & 13.3 & 13.3 & 13.2 \\
\hline Tobacco ${ }^{8)}$ & 12673 & 13237 & 15990 & 14.6 & 14.6 & 14.6 \\
\hline Wearing apparel ${ }^{9)}$ & 70313 & 74705 & 72788 & 12.8 & 13.3 & 13.2 \\
\hline Shoes ${ }^{10)}$ & 17644 & 18384 & 18302 & 10.8 & 11.5 & 11.5 \\
\hline Rent for apartment ${ }^{11)}$ & 102898 & 114045 & 122122 & 3.6 & 3.6 & 3.6 \\
\hline Electricity \& fuel ${ }^{12)}$ & 35941 & 36667 & 39060 & 13.0 & 13.0 & 13.0 \\
\hline Furniture $^{13)}$ & 83965 & 88550 & 88353 & 13.0 & 13.1 & 12.9 \\
\hline Medical \& pharmaceutical products ${ }^{14)}$ & 21461 & 23063 & 23992 & 8.3 & 9.9 & 9.9 \\
\hline Therapeutic instruments ${ }^{15}$ & 3076 & 3108 & 3134 & 10.3 & 10.3 & 10.3 \\
\hline Medical services \& hospitals ${ }^{16)}$ & 23070 & 24516 & 27041 & 0 & 0 & 0 \\
\hline Spa stay in clinics ${ }^{17)}$ & 12115 & 13950 & 14840 & 13.5 & 13.5 & 13.5 \\
\hline Purchase of transportation vehicles ${ }^{18)}$ & 36962 & 39066 & 32896 & 16.6 & 16.6 & 16.0 \\
\hline $\begin{array}{l}\text { Maintenance costs for transportation } \\
\text { vehicles }{ }^{19)}\end{array}$ & 44172 & 47704 & 50199 & 12.8 & 12.8 & 12.8 \\
\hline Charge for transportation services ${ }^{20)}$ & 14809 & 16459 & 17771 & 3.8 & 3.5 & 3.5 \\
\hline Communication service ${ }^{21)}$ & 10791 & 11973 & 12971 & 7.6 & 7.6 & 7.6 \\
\hline Radio, TV, etc. ${ }^{22)}$ & 35855 & 37529 & 36892 & 16.0 & 16.0 & 16.0 \\
\hline Books, magazines \& newspapers ${ }^{23)}$ & 14157 & 14908 & 15701 & 3.8 & 3.8 & 3.8 \\
\hline Education $^{24)}$ & 7029 & 7333 & 7749 & 0 & 0 & 0 \\
\hline Cultural events ${ }^{25)}$ & 21610 & 24362 & 25824 & 15.4 & 15.4 & 15.4 \\
\hline Products \& services for hygiene ${ }^{26)}$ & 27350 & 28916 & 30241 & 15.3 & 15.3 & 15.3 \\
\hline Hotels \& restaurants ${ }^{27)}$ & 86759 & 91879 & 93252 & 8.4 & 8.4 & 8.4 \\
\hline Financial services ${ }^{28)}$ & 4388 & 4646 & 4955 & 0 & 0 & 0 \\
\hline Other goods \& services ${ }^{29)}$ & 35232 & 38164 & 39908 & 8.7 & 8.7 & 8.7 \\
\hline Total $^{30), 31)}$ & 889577 & 949270 & 973178 & & & \\
\hline
\end{tabular}


Notes:

1) The sales of beef and pork as well as hams and sausages (ca. $75 \%$ of the corresponding consumption item) is taxed at the normal VAT rate of $19 \%$. Other types of meat is taxed at the reduced rate of $15 \%$.

2) Prior to 12.5 .1991 fish consumption was generally taxed at the reduced rate of $4 \%$ but thereafter at $9 \%$. Yet, for the sales of crabs, shells and oysters (which comprise ca. 10\% of the total fish consumption) the VAT rate of $12 \%$ applies.

3) For the consumption of fresh milk (ca. $19 \%$ of position) and cheese (54\% of position) the reduced rate of $4 \%$ is adopted, while the imposed rate amounts to $9 \%$ for that of eggs (approximately $8 \%$ of position) and condensed milk (19\% of position).

4) For oil, margarine and butter which comprise $95 \%$ of the total sales of position the reduced VAT rate of $4 \%$ applies. The rate of $9 \%$ is imposed for the consumption of other types of fatty product $(5 \%$ of position).

5) The reduced VAT rate of $9 \%$ is adopted for the entire position.

6) The normal VAT rate of $19 \%$ is imposed on the sales of mineral water and other types of nonalcoholic beverages.

7) The reduced VAT rate of $9 \%$ applied for wine (55\% of the total consumption of alcoholic beverages) until the end of 1992; the rate changed to $12 \%$ in 1993. For beer and spirits (ca. $15 \%$ of position) the normal rate of $19 \%$ applies. The sales of different types of sparkling wine (around $10 \%$ of position) was taxed at the increased rate of $38 \%$ until the end of 1992, and then its rate was reduced to $19 \%$ in 1993.

8) The normal VAT rate of $19 \%$ is adopted for the entire position of which value contains the estimated consumption of smuggled tobacco (ca. 10\%).

9) The consumption of textiles and wearing apparel was taxed at the reduced rate of $9 \%$ in 1991 and 1992, and the rate of $12 \%$ applies for 1993. Maintenance and repair expenses (approximately $44 \%$ of position) are subject to tax at $19 \%$. The increased rate of $38 \%$ applied for fur products ( $1 \%$ of position) was abolished at the end of 1992, of which consumption is taxed instead at the rate of $19 \%$ in 1993.

10) Until 30.4 .1991 the reduced rate of $9 \%$ was adopted but the rate changed to $12 \%$ thereafter. However, shoe repairs (10\% of position) are subject to the normal VAT rate of $19 \%$.

11) Approximately $75 \%$ of the item is tax-free. For water consumption, etc. (ca. $10 \%$ of position) the reduced rate of $9 \%$ is allowed, while the rest (incl. maintenance expenses) is subject to VAT at $19 \%$.

12) Around $40 \%$ of position which consists of the consumption of electricity and also partly gas and coal is subject to tax at the reduced rate of $9 \%$. For the rest of position (central heating and other types of fuel) the normal rate of $19 \%$ applies.

13) House furnishing work ( $10 \%$ of position) is tax-free. The tax rate imposed on the consumption of textiles, bedclothes, etc. which are required for interior decoration ( $5 \%$ of position) was changed from $9 \%$ to $12 \%$ in mid-May 1991 . Otherwise, the normal rate applies. For the consumption of oriental carpets ( $1 \%$ of position) the increased rate of $38 \%$ was adopted until the end of 1992.

14) The sales of medical and pharmaceutical products are generally subject to tax at the reduced rate of $9 \%$. The consumption of some special medicaments (estimated to be ca. $5 \%$ of position) is taxed at the normal rate of $19 \%$. Since 1993 the normal VAT rate applies also for homeopathic products $(5 \%$ of position).

15) For the $50 \%$ of the sales of therapeutic instruments the reduced rate of $4 \%$ is adopted, while the rest is subject to VAT at the normal rate of $19 \%$.

16) Medical care and services in hospitals are tax-free.

17) Spa services provided by private clinics are often taxed at the normal rate of $19 \%$.

18) The consumption of luxury cars (ca. $5 \%$ of position) was subject to tax at the rate of $38 \%$ until the end of 1992. Otherwise, the normal rate of $19 \%$ applies for the item.

19) The expenses for insurance (23\% of position) is tax-free. The normal VAT rate of $19 \%$ applies for the rest.

20) Approximately $65 \%$ of position is tax-free. For carriage of passengers by ship and train $(20 \%$ of position) the reduced rate of $9 \%$ is adopted, while the VAT rate of $12 \%$ applies for passenger transportation by aeroplane (15\% of position) since 1993.

21) Telephone costs (approximately $89 \%$ of position) are taxed at the reduced rate of $9 \%$, while the postal services $(10 \%$ of position) are tax-free. For other communication services ( $1 \%$ of position) the normal rate of $19 \%$ is adopted. 
22) The entire position is subject to VAT at $19 \%$, since the consumption share of records, cassette tapes, etc. appears to be rather negligible which was, however, taxed at the reduced rate of $9 \%$ until the midMay of 1991 and $12 \%$ thereafter.

23) The consumption of entire position is liable to VAT at the reduced rate of $4 \%$.

24) There is no VAT on the education expenses.

25) For cinema, theatre and sport events (60\% of position) the reduced rate of $9 \%$ is allowed. The VAT of $4 \%$ is imposed on the radio and TV licence fee ( $20 \%$ of position). For the rest of position the normal rate of $19 \%$ is adopted.

26) The consumption of normal soap ( $20 \%$ of position) was liable to VAT at the reduced rate of $9 \%$ until the end of 1992 . Otherwise the $19 \%$ rate applies.

27) For the stay in luxury hotels ( $2 \%$ of position) the normal rate of $19 \%$ is adopted. The rest is subject to tax at the reduced rate of $9 \%$.

28) Banks and insurance services are free from VAT.

29) Lotteries and other similar types of wager (30\% of position) are tax-free. For the rest of position the normal rate of $19 \%$ applies.

30) The Italian national accounts system adopts the so-called domestic concept which is a method of determining value added of an economic area, irrespective of whether goods and services are produced by residents or not.

31) The input tax burden for those Italian farmers whose purchase of agricultural goods are subject to VAT but their sales are exempt from the same tax is estimated to be ca. $7 \%$ of their total production value. Therefore, the hypothetical tax revenues from the intermediate consumption and investment of this type of farmers ought to be calculated additionally but such a measurement is not made in the context of the study. Instead, since the tax rates for varied agricultural goods generally amount to (not $0 \%$ but) $4 \%$ or $9 \%$ in Italy, it can be assumed that the extent of extra revenues yielded for the final consumption of different agricultural items largely corresponds to that of anticipated input tax burden of those farmers.

Source: Parsche, Steinherr and Waller (1996), Ursprungslandprinzip and Clearing bei der Mehrwertsteuer - ein makroökonomischer Ansatz, ifo Studien zur Finanzpolitik 61, Munich. 
Table a2 The calculated hypothetical VAT revenues from final consumption of Italian private households (1991-1993)

\begin{tabular}{|c|c|c|c|}
\hline \multirow{2}{*}{$\begin{array}{l}\text { Statistical positions for } \\
\text { Products \& services }\end{array}$} & \multicolumn{3}{|c|}{ Hypothetical VAT revenues in billion Italian Lire (ITL) } \\
\hline & 1991 & 1992 & 1993 \\
\hline Bread \& cereal & 766.7 & 815.0 & 869.4 \\
\hline Meat & 6337.1 & 6611.9 & 6956.3 \\
\hline Fish & 718.7 & 942.1 & 951.3 \\
\hline Milk, cheese \& eggs & 1167.7 & 1214.6 & 1276.9 \\
\hline Oil \& fat & 260.4 & 268.2 & 268.8 \\
\hline Fruit \& vegetables & 1489.6 & 1594.8 & 1481.0 \\
\hline Sugar, coffee, tee $\&$ cacao & 476.8 & 491.7 & 506.9 \\
\hline Other foodstuffs & 439.9 & 462.7 & 482.9 \\
\hline Non-alcoholic beverages & 567.8 & 617.4 & 654.5 \\
\hline Alcoholic beverages & 1254.7 & 1303.9 & 1311.7 \\
\hline Tobacco & 1850,6 & 1933.0 & 2335.0 \\
\hline Wearing apparel & 9034.3 & 9935.6 & 9576.5 \\
\hline Shoes & 1920.2 & 2122.2 & 2112.7 \\
\hline Rent for apartment & 3719.2 & 4122.1 & 4414.0 \\
\hline Electricity \& fuel & 4688.0 & 4782.7 & 5094.8 \\
\hline Furniture & 10943.1 & 11576.8 & 11424.0 \\
\hline Medical \& pharmaceutical products & 1772.0 & 2096.6 & 2181.1 \\
\hline Therapeutic instruments & 317.3 & 320.6 & 323.2 \\
\hline Medical services \& hospitals & 0.0 & 0.0 & 0.0 \\
\hline Spa stay in clinics & 1635.5 & 1883.2 & 2003.4 \\
\hline Purchase of transportation vehicles & 6147.5 & 6497.4 & 5251.7 \\
\hline Maintenance costs for transportation vehicles & 5637.6 & 6088.4 & 6406.8 \\
\hline Charge for transportation services & 566.8 & 571.9 & 617.5 \\
\hline Communication service & 817.8 & 907.4 & 983.0 \\
\hline Radio, TV, etc. & 5724.7 & 5992.0 & 5890.3 \\
\hline Books, magazines \& newspapers & 544.5 & 573.4 & 603.9 \\
\hline Education & 0.0 & 0.0 & 0.0 \\
\hline Cultural events & 3335.2 & 3759.9 & 3985.5 \\
\hline Products \& services for hygiene & 4172.0 & 4410.9 & 4613.0 \\
\hline Hotels \& restaurants & 7309.4 & 7740.7 & 7856.4 \\
\hline Financial services & 0.0 & 0.0 & 0.0 \\
\hline Other goods \& services & 3056.7 & 3311.0 & 3462.3 \\
\hline Total & 86672.0 & 92948.3 & 93895.0 \\
\hline
\end{tabular}

Source: Parsche, Steinherr and Waller (1996), Ursprungslandprinzip and Clearing bei der Mehrwertsteuer - ein makroökonomischer Ansatz, ifo Studien zur Finanzpolitik 61, Munich. 


\section{References}

Aigner, D., F. Schneider and D. Gosh (1988), Me and My Shadow: Estimating the Size of the US Hidden Economy from Time Series Data, in: Barnett, E., R. Berndt and H. White (eds.), Dynamic Econometric Modelling, Cambridge (Mass.): Cambridge University Press, 224-243.

Andreoni, J., B. Erard and J. Feinstein (1998), Tax Compliance, Journal of Economic Literature, Vol. 36, No. 2, 818-860.

Contini, B. (1981), Labour Market Segmentation and the Development of the Parallel Economy - The Italian Experience, Oxford Economic Papers, Vol. 33, No. 4, 401412.

De Gijsel, P. (1984), Ökonomische Theorie des Schwarzarbeitsangebots und der Mehrfachbeschäftigung, in: Gretschmann, K., R. G. Heinze and B. Mettelsiefen (eds.), Schattenwirtschaft. Wirtschafts- und sozialwissenschaftliche Aspekte, internationale Erfahrungen, Göttingen: Vandenhoeck \& Rubrecht, 76-96.

Del Boca, D. (1981), Parallel Economy and Allocation of Time, Micros (Quarterly Journal of Microeconomics), Vol. 4, No. 2, 27-57.

Dziadkowski, D. (1997), Das endgültige Mehrwertsteuersystem im Binnenmarkt eine Utopie?, Steuern und Wirtschaft, No. 2, 147-156.

Dziadkowski, D., A. Gebauer, W. C. Lohse, C. W. Nam and R. Parsche (2002), Entwicklung des Umsatzsteueraufkommens und finanzielle Auswirkungen neuerer Modelle bei der Umsatzbesteuerung, ifo Forschungsberichte, No. 13, Munich: Ifo Institute for Economic Research.

Europäische Kommission (1995), Verfahren der Mitgliedstaaten zur Erhebung und Kontrolle der Mehrwertsteuer, Zweiter Bericht nach Verordnung (EWG, Euratom) No. 1553/89, Art. 12, Brussels and Luxembourg: Amt für Amtliche Veröffentlichungen der EU.

Europäische Kommission (1997), Verfahren der Mitgliedstaaten zur Erhebung und Kontrolle der Mehrwertsteuer, Dritter Bericht der Kommission, Artikel 12 der Verordnung (EWG, Euratom) No. 1553/89, KOM(96) 681 endgültig vom 8.1.1997, Brussels.

Europäische Kommission (2000), Dritter Bericht gemäß Artikel 14 über die Anwendung der Verordnung (EWG) No. 218/92 des Rates vom 27. Januar 1992 über die Zusammenarbeit der Verwaltungsbehörden auf dem Gebiet der indirekten Besteuerung (MwSt.) und Vierter Bericht gemäß Artikel 12 der Verordnung (EWG, Euratom) No. 1553/89 über Verfahren zur Erhebung und Kontrolle der MwSt., KOM(2000) 28 endgültig vom 28.1.2000, Brussels. 
Europäische Kommission (2002), Generaldirektion Steuern und Zollunion, Steuerpolitik, DOC/2908/2002 - DE, May 2002.

Eurostat (1997), National Accounts ESA 1980-1995, Luxembourg and Brussels.

Feige, E. L. (ed. 1989), The Underground Economies. Tax Evasion and Information Distortion, Cambridge et al.: Cambridge University Press.

Feige, E. L. (1996), Overseas Holdings of U.S. Currency and the Underground Economy, in: Pozo, S. (ed.), Exploring the Underground Economy, Kalamazoo: Michigan, $5-62$.

Frey, B. S. (1989), How Large (or Small) Should the Underground Economy Be?, in: Feige, E. L. (ed.), The Underground Economies. Tax Evasion and Information Distortion, Cambridge et al.: Cambridge University Press, 139-149.

Frey, B. S. and W. Pommerehne (1984), The Hidden Economy: State and Prospect for Measurement, Review of Income and Wealth, Vol. 30, No. 1, 1-23.

Frey, B. S. and H. Weck-Hannemann (1984), The Hidden Economy as an "Unobserved" Variable, European Economic Review, Vol. 26, No. 1, 33-53.

Gebauer, A., C. W. Nam, R. Parsche, D. Radulescu and B. Reichl (2002), Möglichkeiten und Risiken der Einführung eines grenzüberschreitenden Vorsteuerabzugs auf europäischer Ebene, ifo Forschungsberichte, No. 12, Munich: Ifo Institute for Economic Research.

Genser, B. (2002), Coordinating VATs between EU Member States, CESifo Working Paper, No. 648(1), Munich.

Isachsen, A. J., J. Klovland and S. Strom (1982), The Hidden Economy in Norway, in: Tanzi, V. (ed.), The Underground Economy in the United States and Abroad, Heath: Lexington, 209-231.

Johnson, S., D. Kaufmann and A. Shleifer (1997), The Unofficial Economy in Transition, Brookings Papers on Economic Activity, Fall, Washington DC.

Kaufmann, D. and A. Kaliberda (1996), Integrating the Unofficial Economy into the Dynamics of Post Socialist Economies: A Framework of Analyses and Evidence, The World Bank Policy Research Working Paper, No. 1691, Washington DC.

Lacko, M. (1998), The Hidden Economies of Visegrad Countries in International Comparison: A Household Electricity Approach, in: Halpern, L. and Ch. Wyplosz (eds.), Hungary: Towards a Market Economy, Cambridge (Mass.): Cambridge University Press, 128-152.

Lippert, O. and M. Walker (eds. 1997), The Underground Economy. Global Evidence of Its Size and Impact, Vancouver: The Fraser Institute.

Lubell, H. (1991), The Informal Sector in the 1980's and 1990's, Paris: OECD.

MacAfee, K. (1980), A Glimpse of Hidden Economy in the National Accounts, Economic Trends, No. 136, 81-87. 
Mennel, A and A. Förster (1999), Steuern in Europa, Amerika und Asien, Herne/Berlin: NWB Verlag.

Mogensen, G., H. K. Kvist, E. Körmendi and S. Pedersen (1995), The Shadow Economy in Denmark 1994: Measurement and Results, The Rockwool Foundation Research Unit Study, No. 3, Copenhagen.

Nam, C. W., R. Parsche and B. Schaden (2001), Measurement of Value Added Tax Evasion in Selected EU Countries on the Basis of National Accounts Data, ifo Studien - Zeitschrift für empirische Wirtschaftsforschung, Vol. 47, No. 2, 127-144.

OECD (1997), Framework for the Measurement of Unrecorded Economic Activities in Transition Economies, OECD Working Paper, No. 93.

OECD (1999), Revenue Statistics 1965/1998: 1999 Edition, Paris.

Parsche, R., M. Steinherr and S. Waller (1996), Ursprungslandprinzip und Clearing bei der Mehrwertsteuer - ein makroökonomischer Ansatz, ifo Studien zur Finanzpolitik, No. 61, Munich: Ifo Institute for Economic Research.

Riebel, V. (1983), Die Schwarzarbeit als Problem der Zeitallokation, Frankfurt am Main: Lang.

Schneider, F. (2000a), Illegal Activities, But Still Value Added Ones (?): Size, Causes and Measurement of the Shadow Economies All over the World, CESifo Working Paper, No. 305.

Schneider, F. (2000b), The Increase of the Size of the Shadow Economy of 18 OECD Countries: Some Preliminary Explanations, CESifo Working Paper, No. 306.

Schneider, F. and D. Enste (2000), Shadow Economies: Size, Causes, and Consequences, The Journal of Economic Literature, Vol. 38, No. 1, 77-114.

Schneider, F. and R. Neck (1993), The Development of the Shadow Economy under Changing Tax Systems and Structures, Finanzarchiv N.F., Vol. 53, No. 3, 344-369.

Tanzi, V. (1982), A Second (and More Sceptical) Look at the Underground Economy in the United States, in: Tanzi, V. (ed.), The Underground Economy in the United States and Abroad, Heath: Lexington, 38-56.

Thomas, J. J. (1992), Informal Economic Activity, LSE Handbooks in Economics, London: Harvester Wheatsheaf. 


\title{
CESifo Working Paper Series
}

\author{
(for full list see www.cesifo.de)
}

908 Robert A.J. Dur and Otto H. Swank, Producing and Manipulating Information, April 2003

909 Christian Gollier, Collective Risk-Taking Decisions with Heterogeneous Beliefs, April 2003

910 Alexander F Wagner, Mathias Dufour, and Friedrich Schneider, Satisfaction not Guaranteed - Institutions and Satisfaction with Democracy in Western Europe, April 2003

911 Ngo Van Long, Raymond Riezman, and Antoine Soubeyran, Trade, Wage Gaps, and Specific Human Capital Accumulation, April 2003

912 Andrea Goldstein, Privatization in Italy 1993-2002: Goals, Institutions, Outcomes, and Outstanding Issues, April 2003

913 Rajshri Jayaraman and Mandar Oak, The Signaling Role of Municipal Currencies in Local Development, April 2003

914 Volker Grossmann, Managerial Job Assignment and Imperfect Competition in Asymmetric Equilibrium, April 2003

915 Christian Gollier and Richard Zeckhauser, Collective Investment Decision Making with Heterogeneous Time Preferences, April 2003

916 Thomas Moutos and William Scarth, Some Macroeconomic Consequences of Basic Income and Employment Subsidies, April 2003

917 Jan C. van Ours, Has the Dutch Miracle Come to an End?, April 2003

918 Bertil Holmlund, The Rise and Fall of Swedish Unemployment, April 2003

919 Bernd Huber and Marco Runkel, Optimal Design of Intergovernmental Grants under Asymmetric Information, April 2003

920 Klaus Wälde, Endogenous Business Cycles and Growth, April 2003

921 Ramon Castillo and Stergios Skaperdas, All in the Family or Public? Law and Appropriative Costs as Determinants of Ownership Structure, April 2003

922 Peter Fredriksson and Bertil Holmlund, Improving Incentives in Unemployment Insurance: A Review of Recent Research, April 2003 
923 Bernard M.S. van Praag and Adam S. Booij, Risk Aversion and the Subjective Time Discount Rate: A Joint Approach, April 2003

924 Yin-Wong Cheung, Kon S. Lai, and Michael Bergman, Dissecting the PPP Puzzle: The Unconventional Roles of Nominal Exchange Rate and Price Adjustment, April 2003

925 Ugo Trivellato and Anna Giraldo, Assessing the 'Choosiness' of Job Seekers. An Exploratory Approach and Evidence for Italy, April 2003

926 Rudi Dornbusch and Stanley Fischer, International Financial Crises, April 2003

927 David-Jan Jansen and Jakob de Haan, Statements of ECB Officials and their Effect on the Level and Volatility of the Euro-Dollar Exchange Rate, April 2003

928 Mario Jametti and Thomas von Ungern-Sternberg, Assessing the Efficiency of an Insurance Provider - A Measurement Error Approach, April 2003

929 Paolo M. Panteghini and Guttorm Schjelderup, Competing for Foreign Direct Investments: A Real Options Approach, April 2003

930 Ansgar Belke, Rainer Fehn, and Neil Foster, Does Venture Capital Investment Spur Employment Growth?, April 2003

931 Assar Lindbeck, Sten Nyberg, and Jörgen W. Weibull, Social Norms and Welfare State Dynamics, April 2003

932 Myrna Wooders and Ben Zissimos, Hotelling Tax Competition, April 2003

933 Torben M. Andersen, From Excess to Shortage - Recent Developments in the Danish Labour Market, April 2003

934 Paolo M. Panteghini and Carlo Scarpa, Irreversible Investments and Regulatory Risk, April 2003

935 Henrik Jacobsen Kleven and Claus Thustrup Kreiner, The Marginal Cost of Public Funds in OECD Countries. Hours of Work Versus Labor Force Participation, April 2003

936 Klaus Adam, George W. Evans, and Seppo Honkapohja, Are Stationary Hyperinflation Paths Learnable?, April 2003

937 Ulrich Hange, Education Policy and Mobility: Some Basic Results, May 2003

938 Sören Blomquist and Vidar Christiansen, Is there a Case for Public Provision of Private Goods if Preferences are Heterogeneous? An Example with Day Care, May 2003

939 Hendrik Jürges, Kerstin Schneider, and Felix Büchel, The Effect of Central Exit Examinations on Student Achievement: Quasi-experimental Evidence from TIMSS Germany, May 2003 
940 Samuel Bentolila and Juan F. Jimeno, Spanish Unemployment: The End of the Wild Ride?, May 2003

941 Thorsten Bayindir-Upmann and Anke Gerber, The Kalai-Smorodinsky Solution in Labor-Market Negotiations, May 2003

942 Ronnie Schöb, Workfare and Trade Unions: Labor Market Repercussions of Welfare Reform, May 2003

943 Marko Köthenbürger, Tax Competition in a Fiscal Union with Decentralized Leadership, May 2003

944 Albert Banal-Estañol, Inés Macho-Stadler, and Jo Seldeslachts, Mergers, Investment Decisions and Internal Organisation, May 2003

945 Kaniska Dam and David Pérez-Castrillo, The Principal-Agent Matching Market, May 2003

946 Ronnie Schöb, The Double Dividend Hypothesis of Environmental Taxes: A Survey, May 2003

947 Erkki Koskela and Mikko Puhakka, Stabilizing Competitive Cycles with Distortionary Taxation, May 2003

948 Steffen Huck and Kai A. Konrad, Strategic Trade Policy and Merger Profitability, May 2003

949 Frederick van der Ploeg, Beyond the Dogma of the Fixed Book Price Agreement, May 2003

950 Thomas Eichner and Rüdiger Pethig, A Microfoundation of Predator-Prey Dynamics, May 2003

951 Burkhard Heer and Bernd Süssmuth, Cold Progression and its Effects on Income Distribution, May 2003

952 Yu-Fu Chen and Michael Funke, Labour Demand in Germany: An Assessment of NonWage Labour Costs, May 2003

953 Hans Gersbach and Hans Haller, Competitive Markets, Collective Decisions and Group Formation, May 2003

954 Armin Falk, Urs Fischbacher, and Simon Gächter, Living in Two Neighborhoods Social Interactions in the LAB, May 2003

955 Margarita Katsimi, Training, Job Security and Incentive Wages, May 2003

956 Clemens Fuest, Bernd Huber, and Jack Mintz, Capital Mobility and Tax Competition: A Survey, May 2003 
957 Edward Castronova, The Price of 'Man' and 'Woman': A Hedonic Pricing Model of Avatar Attributes in a Synthetic World, June 2003

958 Laura Bottazzi and Marco Da Rin, Financing Entrepreneurial Firms in Europe: Facts, Issues, and Research Agenda, June 2003

959 Bruno S. Frey and Matthias Benz, Being Independent is a Great Thing: Subjective Evaluations of Self-Employment and Hierarchy, June 2003

960 Aaron Tornell and Frank Westermann, Credit Market Imperfections in Middle Income Countries, June 2003

961 Hans-Werner Sinn and Wolfgang Ochel, Social Union, Convergence and Migration, June 2003

962 Michael P. Devereux, Measuring Taxes on Income from Capital, June 2003

963 Jakob de Haan, Jan-Egbert Sturm and Bjørn Volkerink, How to Measure the Tax Burden on Labour at the Macro-Level?, June 2003

964 Harry Grubert, The Tax Burden on Cross-Border Investment: Company Strategies and Country Responses, June 2003

965 Kirk A. Collins and James B. Davies, Measuring Effective Tax Rates on Human Capital: Methodology and an Application to Canada, June 2003

966 W. Steven Clark, Using Micro-Data to Assess Average Tax Rates, June 2003

967 Christopher Heady, The 'Taxing Wages' Approach to Measuring the Tax Burden on Labour, June 2003

968 Michael P. Devereux and Alexander Klemm, Measuring Taxes on Income from Capital: Evidence from the UK, June 2003

969 Bernhard Eckwert and Itzhak Zilcha, The Effect of Better Information on Income Inequality, June 2003

970 Hartmut Egger and Josef Falkinger, The Role of Public Infrastructure for Firm Location and International Outsourcing, June 2003

971 Dag Morten Dalen and Trond E. Olsen, Regulatory Competition and Multi-national Banking, June 2003

972 Matthias Wrede, Tax Deductibility of Commuting Expenses and Residential Land Use with more than one Center, June 2003

973 Alessandro Cigno and Annalisa Luporini, Scholarships or Student Loans? Subsidizing Higher Education in the Presence of Moral Hazard, June 2003

974 Chang Woon Nam, Andrea Gebauer and Rüdiger Parsche, Is the Completion of EU Single Market Hindered by VAT Evasion?, June 2003 